\title{
GOVERNANCE COMMUNICATION AS A SUB-DIMENSION IN NON-GOVERNMENTAL INSTITUTIONS: APPLICATION AT AVIATION SECTOR
}

\author{
DOI: 10.17261/Pressacademia.2021.1424 \\ PAP- V.13-2021(13)-p.62-68
}

Harun Yilmaz ${ }^{1}$, Savas S. Ates ${ }^{2}$, Sinasi Muratoglu ${ }^{3}$

${ }^{1}$ Iskenderun Technical University, Aviation Management, Hatay, Turkey harun.yilmaz@iste.edu.tr, ORCID: 0000-0002-8467-9019

2 Eskisehir Technical University, Aviation Management, Eskisehir, Turkey, ssates@eskisehir.edu.tr, ORCID: 0000-0003-2462-0039

${ }^{3}$ Association of Civil Aviation Safety Officers (SIHAGUVDER), Ankara, Turkey

sinasimuratoglu@hotmail.com , ORCID: 0000-0001-8057-6090

\section{To cite this document}

Yilmaz, H., Ates, S.S., Muratoglu, S., (2021). Governance communication as a sub-dimension in non-governmental institutions: application at aviation sector. PressAcademia Procedia (PAP), V.13, 62-68.

Permanent link to this document: $h$ ttp://doi.org/10.17261/Pressacademia.2021.1424

Copyright: Published by PressAcademia and limited licensed re-use rights only.

\section{ABSTRACT}

Purpose- In this study, besides revealing the role and importance of communication in the governance process, it is aimed to determine the understanding of civil society and the communication status of the non-governmental organization that is its representative.

Methodology- The research was carried out with 357 participants who are members of the Airport Security Officers Association (SIHAGÜVDER), the only non-governmental organization in the field of civil aviation security in Turkey.

Findings- National non-governmental organizations can reach their members by establishing representative offices. Word of mouth communication from local NGO representatives (19.2\%) and their friends $(13.9 \%)$ are important communication tools. The least preferred communication technique of the responding NGO members is the internet page and other social media (instegram, twitter etc.) tools.

Conclusion- Governance understanding is gaining importance day by day for the strengthening and development of non-governmental organizations. In order for the governance process to be efficient, it has been understood that all communication channels are not used at a sufficient level between the members of the management and other members.

Keywords: Governance, communication, civil society, non-governmental organization, SIHAGUVDER.

JEL Codes: G30, L30, M10

\section{SIVIL TOPLUM KURULUŞLARINDA YÖNETIŞiM BíR ALT BOYUT OLARAK ILETiŞiM: HAVACILIK ALANINDA UYGULAMA}

\section{ÖZET}

Amaç- Bu çalışmada, yönetişim sürecinde iletişimin rolünü ve önemini ortaya koymanın yanında sivil toplum anlayışı ve onun temsilcisi olan sivil toplum kuruluşunun iletişim durumunu tespit etmek amaçlanmıştır.

Metodoloji - Araştırma Türkiye'nin sivil havacılık güvenliği alanında tek sivil toplum kuruluşu olan Havalimanları Güvenlik Memurları Derneğ (SIHAGÜVDER) üyesi 357 katılımcı ile gerçekleştirilmiştir.

Bulgular- Ulusal sivil toplum kurulușları temsilcilikler kurarak üyelerine ulaşabilmektedir. Yerel STK temsilcisi $(\% 19,2)$ ve arkadaşlarından $(13,9)$ kulaktan kulağa iletişim önemli iletişim araçlarıdır. Cevap veren STK üyelerinin en az tercih ettikleri iletişim tekniği internet sayfası ve diğer sosyal medya (instegram, twitter vb.) araçlarıdır.

Sonuç - Sivil toplum kuruluşlarının güçlendirilmesi ve gelişmesi için yönetişim anlayışı gün geçtikçe önem kazanmaktadır. Yönetişim sürecinin verimli olabilmesi amacıyla tüm iletişim kanallarının üyelerin yönetim ve diğer üyeler arasında yeterli bir düzeyde kullanılmadı̆̆ı anlaşılmıştır.

Anahtar Kelimeler: Yönetişim, iletişim, sivil toplum, sivil toplum kuruluşu, SIHAGUVDER.

JEL Kodları: G30, L30, M10

\section{Giriş}

Hızlı bir değişim dünyasında, etkili ve anlamlı topluluk katılımı, bireyin ya da devletin güvenliğinin temelini oluşturmaktadır. Katılımın doğası hakkında net bir anlayış, barış, sosyal adalet ve demokrasi arayışının merkezinde yer alır (Abbott, 2013). Sivil toplum ve bu anlayışa dayalı sivil toplumculuk, devletin ve piyasanın dışında kalan alandır (Doğan, 2016). Bu açıdan sivil toplum kuruluşları toplum için fayda sağlama üzerine kurulmuş demokratik yapının bir parçasıdır. 
Kurumlarda demokratik geleneğin oluşturulmaması veya katı kurumsal geleneklere sahip örgüt iklimleri, sivil toplumun gelişmesinin önündeki engeller arasında yer almaktadır. Bu engellerin kaldırılması ve sivil toplum kuruluşlarının gelişmesini sağlamak için yeni bir yönetim tarzına intiyaç duyulmaktadır. Bu yönetim tarzında tüm paydaşların etkileşim, işbirliği ve ortaklık içinde hareket etmeleri gerekir.

Havacılık endüstrisinde de kamu ve özel sektöründen başka sivil toplum kuruluşları da etkin olma çabası içindedir. Bu etkinliğin sağlanması amacıyla sektörde faaliyet gösteren kurum/kuruluş ve işletmeler karşılıklı işbirliği yapmaktadır. Havacılık sektöründe sunulan hizmetlerden başında güvenlik hizmeti gelmektedir. Güvenlik hizmetinin sunulmasında yer alan paydaşların en önemlisi insan kaynağıdır. Geniş bir sorumluluk alanına sahip havaalanı güvenlik personeli, son gelişmiş teknolojiyi kullanarak ve mevzuattaki gelişmeleri takip ederek görev yapmaktadır. Ortaya çıkan güvenlik sorunlarının temelinde insan faktörünün etkili olduğu havaalanı güvenlik sisteminde, personel, yetki karmaşasına maruz kalmaktadır. Bu durum da personelin üzerinde bir baskı oluşturmaktadır. Havaalanı güvenlik personelinin sahip olduğu özellikleri, yetki ve sorumluluk alanlarının desteklenmesi ile bu baskının azalacağı düşünülmektedir.

İletişim bugün tüm insanlar ve topluluklar için hayati bir öneme sahiptir. Çünkü ortak bir amacı gerçekleştirmek için bir araya gelmişlerdir. Gruplar ve bireyler iletişim olgusuyla bir birlerine ve örgüte bağlanırlar. İletişim, bir arada yaşayan insanlar açısından sembolik mesajların ve anlamların paylaşılması sürecidir. Örgütsel yapının iletişim aracılığıyla oluşturulduğu örgütlerde bir iletişim yansıması bulunmaktadır (Durğun, 2006). Örgüt içerisindeki bilgi resmi ve resmi olmayan yapılarda üst yönetimden alt yönetime, alt yönetimden üst yönetime ve yatay olarak iletilir (Atak, 2005). Örgüt, önceden belirlenen amaçlara ulaşabilmek için görev tanımlarının belirlenmesi ve bu görevlerin yapılacağı zaman ve kişilerin çok iyi bilinmesi gerekir.

Örgüt çalışanları arasındaki uyum ve iyi ilişkiler doğru iletişime bağlıdır. Doğru iletişim ile örgütsel unsurlar arasındaki yüksek dayanışma ve koordinasyon sağlanabilir. İletişimdeki uyum ve örgütsel etkinliği artıracak ve çalışanlar arasında güçlü bir bağ oluşturur (Atak, 2005).

Bu çalışmada, yönetişim sürecinin en önemli unsuru olan iletişimin rolünü ve önemini ortaya koymak ve sivil toplum anlayışı ile sivil toplum kuruluşundaki iletişim sürecini ve durumunu tespit etmek amaçlanmıştır. Bu amaç doğrultusunda, öncelikle yönetişim kavramının ve alt boyutu olan iletişimin STK'lar açısından önemi irdelenmiş olup (SiHAGÜVDER)'in üyelerinin iç iletişim süreçleri değerlendirilmiştir.

\section{LITERATÜR}

\subsection{Yönetişim}

Kamu yönetimi çalışmalarına 1990'lı yıllardan sonra girmiş olan yönetişim kavramı, önce uluslararası kurum ve kuruluşlar tarafından yayımlanan raporlarda daha sonra akademik çalışma ve tartışmalarda incelenmeye başlanılmıştır (Sobacı, 2007). iletişim ve birlikte iş yapma özelliğiyle, örgütteki ortamı zengin hale getirmekte ve bireyleri örgüt amaçlarını benimsemek ve gerçekleştirmek için motive eden (Fidan, 2011) Yönetişim temelinde, devletin haricinde özel sektör ve sivil toplum kuruluşlarının da yönetimde söz sahibi olmaları vurgulanmaktadır. Böylece çok aktörlü ve karşılıklı etkileşimin olduğu bir yönetim anlayışı olarak ortaya çıkan yönetişim, birlikte karar almayı ve eyleme geçilmesini, kaynak bağımlılığını ve ortak amaçlar üzerinde görüşmelerin yapılmasını zorunlu kılar (Tarihi Bilgi, 2020).

Yönetim ve iletişim kelimelerinden türetilmiş (Fidan, 2011) yönetim süreci ve davranışıyla ile ilgili olan yönetişim, tarafların birbirini yönetmesinden, karşılıklı etkileşimlerin yaşandığı ilişkiler bütününe doğru evrilmiştir. (Öksüz, 2014). Yönetişim sürecinde yer alan fonksiyonlar; iletişim ve etkin bilgi paylaşımı, empati, duygusal zekâ, beyin fırtınasına dayalı müşterek karar verme, proaktif düşünce, sinerji, güçlendirme, şeffaflık ve çok yönlü güven kavramlarıdır (Fidan, 2011). Özellikle yönetişimin şeffaf bir karar alma sürecini ifade eden saydamlık ve kararların alınmasına katılım şeklinde özellikleri mevcut olup (Sobacı, 2007) bu süreçte, iç ve dış paydaşlara düzenli bilgi akışı gerçekleşmektedir (Öksüz, 2014).

Yönetişim, "hiyerarşik" ve "tepedenci" bir yönetim yerine, "yatay ilişkiler temelinde yükselen”, "tabana dayalı”, "gücünü halktan alan”, "desantralize", "katılımcı", "şeffaf", "demokratik denetime ve hesap vermeye açık" politikalar, örgütler ve hareketler üzerinde yer alan yeni bir ilişkiler sisteminin gelişmesidir (Ataay, 2006). İyi yönetişim anlayışında ise yerel kalkınma, katılım ve diyalog ile sürdürülebilir kalkınma yer almaktadır (Gündüz, 2014). Cadbury Raporu (1992)'ye göre, birleşik veya sistematik bir teoriden yoksun karmaşık ve çok yönlü bir konu olan yönetişimin paradigması, teşhisi ve çözümleri ekonomi, muhasebe, finans ve diğer alanları kapsayan multidisipliner alanlarda yatmaktadır. Yönetişim kavramının sistemsel boyutunda yer alan sivil toplum kuruluşlarına güç ve yetkinin dağıtımı benimsenmektedir (Sobacı, 2007).

\section{2. İletişim}

Bilgi ve anlamanın bir kimseden başka bir kimseye geçişi diye tanımlanan iletişim insanlar arasında anlamlı etkileşim sağlama sürecidir (Yıldırım, Arıkan, \& Aşan, 1996). İletişim sadece insanlar için değil aynı zamanda örgütler, topluluklar ve daha büyük kütleler için de vazgeçilmez bir unsurdur. İletişim, insanlar arasındaki bilgi ve mesaj aktarımının belirli bir iletişim kanalı kullanılarak tek yönlü veya iki yönlü olarak yazılı, sözlü ve sözsüz olarak gerçekleşmektedir (Özmutaf \& Çelikli, 2010). Kişinin iç dünyasında başlayan iletişim, bireylerin birbirleri ile grup içinde ve örgüt bünyesinde, kitlesel biçimde ve teknolojik düzeylerde karşımıza çıkan bir olgudur (Karaçor \& Şahin, 2004).

İletişim şemasına göre altı tane iletişim elemanı bulunmaktadır. Bir kişi, kurum veya örgüt gönderen (konuşan) ve bir kişi, canlı hayvan veya bir makine dinleyen (alan), iletilen bilgilerin muhtevası ve amacı Mesaj, mesajları taşıyan vasıta İletişim kanalı, kullanılan sözlü veya yazılı dil KOD ve son olarak iletişim metninden oluşmaktadır (Öztürk, 1999).

Yöneticiler ile çalışanlar arasında, yönetici ve çalışanlarla işletme dışı organlar arasında anlaşmayı sağlamak amacıyla bilgi, düşünce, his, tutum ve davranışların iletilmesi işlemidir (Yıldırım, Arıkan, \& Aşan, 1996).

İletişim örgütler için de vazgeçilmez bir unsurdur. Çünkü örgütte koordineli bir şekilde hareket edilmekte olup, iki veya daha fazla kişinin bir hedefe ulaşmak için birleşmişlerdir (Robbins \& Judge, 2012). Bir örgütteki çalışanların birbirlerini iyi tanıması ve anlaması, görevini daha iyi yapması ve sorunların daha kolay çözülmesi için daha iyi bir iletişime ihtiyaç vardır (Seyitoglu \& Yüzbaşıoğlu, 2015). 
Daha geniş iletişim çalışmaları alanında iyi kurulmuş bir alt disiplin olan (Marques, 2010) örgütsel iletişim, iş performansı ve birey-örgüt ilişkilerini güçlendirmek için kritik öneme sahip (Walden, 2019) olup bireylerin bilgi alışverişi aracılığıyla tutumlarını ve davranışlarını karşılıklı etkileme ve değiştirme sürecidir (Kılıç \& Saygılı, 2019). Örgütteki iletişimin etkin olması hedeflenmektedir. Aksi takdirde örgüt içerisinde iş tatmini ve hizmet kalitesi olumsuz yönde etkilenecektir (Çelikdemir \& Paker, 2019).

Uzun vadede başarılı olmak isteyen her örgütün arka planında etkin iletişim süreçleri yatmaktadır (Ergle, 2015). Örgütsel iletişim, kâr amacı güden veya gütmeyen, iş veya akademik temelli olsun, her tür organizasyonun başarı oranında çok önemli bir unsur olduğunu göstermiştir (Marques, 2010).

Örgütsel iletişimin hem bireyler hem de örgütler açısından birçok faydası vardır. Örgütsel iletişim yapı bakımından formal ve informal iletişim olmak üzere ikiye ayrılır. Formal (resmi veya biçimsel) iletişim, kurallar çerçevesinde ve örgütün amaçları doğrultusunda belli kalıplara göre gerçekleşmektedir. Resmi toplantılar ve prosedürler gibi formal kanallar aracılığıyla gerçekleşebilmektedir (Efeoğlu \& Çetin, 2012). İnformal (resmi veya biçimsel olmayan) iletişim, yüz yüze veya telefon ile çalışanlar arasında gerçekleşen iletişimdir (Tutar, 2013).

\subsection{Sivil Toplum Kuruluşunda İletişimin Rolü}

Sivil toplum, insanların rahatlıkla ilişki geliştirebildikleri, sosyokültürel etkinliklerde bulunabildikleri gönüllü olarak kendi kendini oluşturan devletten ayrı, özel alan ile devlet arasında aracı niteliğinde olan örgütsel bir sosyal yapılanmadır (Sobacı, 2007). Buradaki en önemli özellik de insanların ortak çıkarlarını geliştirmek için bir araya gelmeleridir. Vatandaşların politika geliştirmeye dâhil edilmesi, yaygın olarak iyi yönetişimin temel unsuru olarak kabul edilir. Devlet yönetiminde vatandaş katılımı için üzerinde uzlaşıya varılmış teorik bir temelin olmaması en büyük problemdir (Abbott, 2013). İnsanların ortak çıkarları için bir araya geldikleri alan içerisinde faaliyet gösteren, toplumsal fayda sağlayan ve toplumsal sorumluluğu temel alan örgütlenmeler olan sivil toplum kuruluşları (STK) ortaya çıkmıştır (Özdemir, 2010). Sivil toplum kuruluşları, resmi kurumlardan bağımsız olarak çalışan, politik, sosyal, kültürel, hukuki ve çevresel amaçları doğrultusunda bir araya gelen, üyelerini gönüllüğe dayalı kabul eden, kâr amacı gütmeyen kuruluşlardır (Gündüz, 2014)

Devlet merkezli olmaktan uzaklaşarak toplumsal inisiyatifle desteklenen bir karakter elde etme ve küreselleşme eğiliminde (Esen, 2014) olan STK'lar, devlet ilişkilerinde, devlet ve sivil toplum tarafından demokrasinin tam anlamıyla nitelendirilememesinden ya da toplumdaki siyasal kültürden kaynaklanan çeşitli sorunlar yaşayabilmektedir (Gümüş, 2014). Sivil toplum kuruluşları, kendi amaç ve değerlerine hizmet etmenin yanında hükümetlerden ve kamu kurumlarından bağımsız bir şekilde harekete etmekte, ticari çıkar gözetmeden kar amacı gütmez ve merkezi yönetim ile insanlar arasında arabuluculuk yapmaktadır (Özer, 2008).

STK'lar yapıları gereği iletişim faaliyetlerinde sadece devlet ile değil iç ve dış çevreleriyle de yoğun bir iletişim faaliyeti gerçekleştirmektedirler (Bozkanat, 2020). (Yavuzyılmaz \& Akıncı, 2017) yaptığı çalışmada STK'ların iç ve dış çevreleriyle iletişim faaliyetlerini bütünleşik iletişim olarak adlandırmışlardır. STK'ların web sitelerinin incelenmesinde, sivil toplum, halkla ilişkiler ve interneti bir arada ele alan "diyolojik iletişim" araştırılan konulardan biridir (Özdemir, 2010) (Aydın \& Aliyeva, 2019). Günümüzde STK'ların yaşadığı iletişim sorunları bulunmaktadır. Bunlar (Esen, 2014):

- $\quad$ STK'lar arasında iletişimin az ve iş birliklerinin yetersiz olması.

- Devlet-STK ilişkilerinin istenen seviyeye gelmemiş olması.

- STK'ların yönetim konusundaki yetersizlikleri.

Özmutaf ve Çelikli (2010)'nun yaptığı çalışmada STK'lardaki iletişim; bireysel, örgüt içi ve örgüt dışı çevreye yönelik oluşturulan 3 boyut yasal çevre ve gönüllülük felsefesi olarak 2 alt alanda incelemiştir (Özmutaf \& Çelikli, 2010). Kişiler arası ilişkiler çerçevesinde belirli yazılı / yasal kurallar ve daha çok STK'yı oluşturan kişilerin birbirleriyle olan sosyo-demografik ya da çıkar aynılığı gibi konular çerçevesinde gönüllülük perspektifinde ortak paydada buluşmalarıdır. STK'larda örgüt içi boyut ise yine yasal çerçeve kapsamında daha çok biçimsel iletişimi içine almakta olup bir örgüt yapılanmasının genel kurul, yönetim kurulu, denetim kurulu mutlaka olması gerekli yasal kurulların yine gönüllülük perspektifinde iletişime geçilmesidir. STK'nın dış çevresindeki paydaşları ve hedef kitlesi ile de genellikle yasal çerçevede finansal ya da fiziksel kaynaklara ulaşma açısından iletişim süreçleri gerçekleştirilmektedir.

Bu çalışmada sivil toplum kuruluşu olarak Türk sivil havacılık sektöründe faaliyet gösteren Havalimanları Güvenlik Memurları Derneği (SiHAGÜVDER) üzerinde bir uygulama yapılmıştır. Sivil havacılık güvenliği ile ilgili Türkiye'nin ilk ve tek STK'sı olan Havalimanları Güvenlik Memurları Derneği (SiHAGÜVDER), 03.08.2012 tarihinde Ankara'da kurulmuştur. Derneğin üyeleri sivil havalimanlarında 1996 yılından bu yana D.H.M.I. Genel Müdürlüğü bünyesinde Havacılık Acil Yardım ve Güvenlik Dairesi Başkanlığı'na bağlı personelden oluşmaktadır. Derneğin amacı Türkiye Sivil Havacılığının gelişimine ve özendirilmesine katkıda bulunmaktır. Bu amaçla sivil havacılık güvenliği bilincini ve hizmet kalitesini artırmak için konu ile ilgili eğitim, araştırma, tanıtım faaliyetlerini hedef olarak belirlemiştir. Bu kapsamda SiHAGÜVDER'deki yönetişim sürecinde üyeler ve yönetim arasındaki iletişim faaliyetleri analiz edilmiştir.

\section{METODOLOJi}

Sivil toplum kuruluşlarında yönetişim ve iletişim konularını inceleyen akademik çalışma sayısının yeterli olmaması sebebiyle yapılan bu araştırma keşifsel bir araştırmadır.

STK'lar yapıları gereği iç ve dış paydaşlar ile etkileşim içindedir. STK'larda iç paydaş etkileşimleri bireyler arası iletişimle mümkündür. STK üyelerinin iletişiminde açıklık ve anlaşılır olmak uygulama süreçlerini ve dış paydaş ilişkilerini de etkileyecektir. STK üyeleri temsilcilerle, temsilciler de yönetim ekibi ile açık, net, zamanında ve verimli iletişim kurabilmesi gerekir.

Araştırmanın temel amacı, sivil toplum anlayışı ve onun temsilcisi olan sivil toplum kuruluşunun iletişim durumunu tespit etmektir. Araştırmada STK örneklerinden (SiHAGÜVDER)'in üyelerinin iç iletişim süreçleri değerlendirilmiştir. Araştırma veri toplama yöntemi olarak likert tipi temel alan bir ölçek geliştirilmiştir. 
Araştırma kapsamında dernek üyesi 1740 kişiye ölçek e-posta, whatsapp, sosyal medya ve SMS yoluyla iletilmiştir. Araştırma soruları katııımcılara Eylül 20019 yılında yollanmıştır. Internet üzerinden yapılan anket Kasım 2009 tarihine kadar açık kalmıştır. Araştırmaya cevap verenlerden 357 katılımcının cevapları geçerli sayılıp analize dâhil edilmiştir.

\section{ANALIZ VE BULGULAR}

Araştırma kapsamında ankete katılan STK üyelerinin \%97,5’i 36-49 yaş gurubunda yer almaktadır (Tablo 1). Bunun temel sebebi Sivil Havacılık Güvenliğine yönelik memurlarının alımının 7 yıl devam etmesi ardından da güvenlik hizmetinin özel güvenlik şirketlerince üstlenilmesidir.

Tablo 1: Yaş Dağılımı

\begin{tabular}{rrrrrr}
\hline & & Frequency & Percent & Valid Percent & Cumulative Percent \\
\hline Valid & $36-42$ & 67 & 18,7 & 18,7 & 18,7 \\
& $43-49$ & 283 & 78,8 & 78,8 & 97,5 \\
& $50-55$ & 9 & 2,5 & 2,5 & 100,0 \\
& Total & 359 & 100,0 & 100,0 & \\
\hline
\end{tabular}

Katılımcıların \%90’ı ön lisans veya lisans eğitim derecesine sahipken lise ve dengi okuldan mezun oranı \%7,5'tir. Lisansüstü eğitim almış olan 9 kişi bulunmaktadır. Güvenlik görevlilerinden biri Yönetim ve Organizasyon alanında doktora mezunudur (Tablo 2).

Tablo 2: Eğitim Durumu

\begin{tabular}{llrrrr}
\hline & Frequency & Percent & Valid Percent & Cumulative Percent \\
\hline Valid & Lise & 27 & 7,5 & 7,5 & 7,5 \\
& Ön Lisans & 104 & 29,0 & 29,0 & 36,5 \\
& Lisans & 219 & 61,0 & 61,0 & 97,5 \\
& Lisansüstü & 9 & 2,5 & 2,5 & 100,0 \\
& Total & 359 & 100,0 & 100,0 & \\
\hline
\end{tabular}

Araştırma kapsamında STK üyelerinin yönetim kurulu ve yerel temsilci ile görüşme sıklıkları ve iletişim için tercih ettiği iletişim araçları sorulmuştur.

Yerel STK temsilcisi ile iletişimde kullanılan araçlar ve iletişim sıklığı

Araştırmaya katılan STK üyelerinin $\% 13,6$ 'sı yerel STK temsilci ile hiç cep telefonu ile görüşmediklerini belirtmişlerdir. Bunun yanında katılımcıların \%51,5 ayda bir ve daha fazla yerel STK temsilcisi ile cep telefon ile görüşmektedir (Tablo 3).

Tablo 3: Yerel STK Temsilcisini Cep Telefonu İle Sesli Arama

\begin{tabular}{llrrrr}
\hline & Frequency & Percent & Valid Percent & Cumulative Percent \\
\hline Valid & Hiç iletişime geçmedim & 49 & 13,6 & 13,6 & 13,6 \\
& Yılda birkaç kez & 71 & 19,8 & 19,8 & 33,4 \\
& Ayda birkaç kez & 94 & 26,2 & 26,2 & 59,6 \\
& Haftada birkaç kez & 91 & 25,3 & 25,3 & 85,0 \\
Her gün & 54 & 15,0 & 15,0 & 100,0 \\
& Total & 359 & 100,0 & 100,0 & \\
\hline
\end{tabular}

Akıllı cep telefonları için ilk olarak 2012 yılında çıkmış olan iletişim platformu olan whatsapp tüm dünyada yaygın kullanılan iletişim platformlarından biridir. Araştırmaya katılan STK üyelerinin cevapları cep telefonu ile paralellik göstermektedir. Ankete katılanlardan \%13,1'i yerel STK temsilci ile hiç whatsapp ile görüşmediklerini belirtmişlerdir. Bunun yanında \%59,9'u ayda veya haftada birkaç kez yerel STK temsilcisi ile whatsapp ile iletişim kurduklarını belirtmiştir (Tablo 4).

Tablo 4: Yerel STK Temsilcisiyle Whatsapp ile Illetişim

\begin{tabular}{llrrrr}
\hline & Frequency & Percent & Valid Percent & Cumulative Percent \\
\hline Valid & Hiç iletişime geçmedim & 47 & 13,1 & 13,1 & 13,1 \\
& Yılda birkaç kez & 54 & 15,0 & 15,0 & 28,1 \\
& Ayda birkaç kez & 93 & 25,9 & 25,9 & 54,0 \\
& Haftada birkaç kez & 104 & 29,0 & 29,0 & 83,0 \\
& Her gün & 61 & 17,0 & 17,0 & 100,0 \\
& Total & 359 & 100,0 & 100,0 & \\
\hline
\end{tabular}

İş hayatında elektronik posta sıkılıkla kullanılan iletişim araçlarından biridir. Ankete cevap veren STK üyelerinin yaklaşık \%40'ı yerel STK temsilcileri ile e-posta ile hiç iletişime geçmediğini belirtmişlerdir (Tablo 5).

Tablo 5: Yerel STK Temsilcisiyle E-posta ile İletişim

\begin{tabular}{rrrrrr}
\hline & & Frequency & Percent & Valid Percent & Cumulative Percent \\
\hline Valid & Hiç iletişime geçmedim & 143 & 39,8 & 39,8 & 39,8 \\
\hline
\end{tabular}




\begin{tabular}{lrrrr}
\hline Yılda birkaç kez & 73 & 20,3 & 20,3 & 60,2 \\
Ayda birkaç kez & 67 & 18,7 & 18,7 & 78,8 \\
Haftada birkaç kez & 35 & 9,7 & 9,7 & 88,6 \\
Her gün & 41 & 11,4 & 11,4 & 100,0 \\
Total & 359 & 100,0 & 100,0 & \\
\hline
\end{tabular}

Araştırmaya katılan STK üyelerinin \%10,6'sı yerel temsilcilerle yüz yüze hiç iletişime geçmediklerini belirtmişlerdir (Tablo 6).

Tablo 6: Yerel STK Temsilcisiyle Yüz Yüze illetişim

\begin{tabular}{llrrrr}
\hline & Frequency & Percent & Valid Percent & Cumulative Percent \\
\hline Valid & Hiç iletişime geçmedim & 38 & 38 & 10,6 & 10,6 \\
& Yılda birkaç kez & 71 & 19,8 & 19,8 & 30,4 \\
& Ayda birkaç kez & 72 & 20,1 & 20,1 & 50,4 \\
& Haftada birkaç kez & 118 & 32,9 & 32,9 & 83,3 \\
Her gün & 60 & 16,7 & 16,7 & 100,0 \\
& Total & 359 & 100,0 & 100,0 & \\
\hline
\end{tabular}

STK Başkanı veya Yönetim Kurulu Üyeleri ile iletişimde kullanılan araçlar ve iletişim sıklığı

STK üyelerinin başkan veya yönetim kurulu ile iletişime geçme sıklığı ve kullanılan araçlar analiz edildiğinde araştırmaya katılanlardan yaklaşık \%40’ı başkan veya yönetim kurulu ile telefon ile görüşmediklerini belirtmişlerdir (Tablo 7).

Tablo 7: STK Başkanı veya Yönetim Kurulu Üyelerini Cep telefonu ile sesli arama

\begin{tabular}{llrrrr}
\hline & Frequency & Percent & Valid Percent & Cumulative Percent \\
\hline Valid & Hiç iletişime geçmedim & 144 & 40,1 & 40,1 & 40,1 \\
& Yılda birkaç kez & 116 & 32,3 & 32,3 & 72,4 \\
& Ayda birkaç kez & 59 & 16,4 & 16,4 & 88,9 \\
& Haftada birkaç kez & 22 & 6,1 & 6,1 & 95,0 \\
& Her gün & 18 & 5,0 & 5,0 & 100,0 \\
& Total & 359 & 100,0 & 100,0 & \\
\hline
\end{tabular}

Araştırmaya katılan STK üyelerinin yaklaşık \%42'si başkan veya yönetim kurulu ile Whatsapp ile görüşmediklerini belirtmişlerdir. Yılda birkaç kez whatsapp ile iletişime geçenlerin oranı \%25,9'dur (Tablo 8).

Tablo 8: STK Başkanı veya Yönetim Kurulu Üyeleriyle Whatsapp İle İletişim

\begin{tabular}{llrrrr}
\hline & Frequency & Percent & Valid Percent & Cumulative Percent \\
\hline Valid & Hiç iletişime geçmedim & 151 & 42,1 & 42,1 & 42,1 \\
& Yılda birkaç kez & 93 & 25,9 & 25,9 & 68,0 \\
& Ayda birkaç kez & 67 & 18,7 & 18,7 & 86,6 \\
Haftada birkaç kez & 28 & 7,8 & 7,8 & 94,4 \\
Her gün & 20 & 5,6 & 5,6 & 100,0 \\
Total & 359 & 100,0 & 100,0 & \\
\hline
\end{tabular}

Ankete cevap verenlerin başkan veya yönetim kurulu ile iletişimde en az kullanılan tekniğin \%51,5 ile e-posta olduğu görülmüştür (Tablo 9).

Tablo 9: STK Başkanı veya Yönetim Kurulu Üyeleriyle E-posta İle İletişim

\begin{tabular}{llrrrr}
\hline & Frequency & Percent & Valid Percent & Cumulative Percent \\
\hline Valid & Hiç iletişime geçmedim & 185 & 51,5 & 51,5 & 51,5 \\
& Yılda birkaç kez & 86 & 24,0 & 24,0 & 75,5 \\
& Ayda birkaç kez & 60 & 16,7 & 16,7 & 92,2 \\
Haftada birkaç kez & 11 & 3,1 & 3,1 & 95,3 \\
Her gün & 17 & 4,7 & 4,7 & 100,0 \\
Total & 359 & 100,0 & 100,0 & \\
\hline
\end{tabular}

Ankete cevap veren STK üyelerinden başkan veya yönetim kurulu ile iletişimde yılda birkaç kez yüz yüze iletişime geçenlerin oranı \%29,3'tür (Tablo 10). Başkan veya yönetim kurulu üyeleriyle iletişimde en az tercih edilen ikinci tekniğin yüz yüze iletişim olduğu belirlenmiştir.

Tablo 10: STK Başkanı veya Yönetim Kurulu Üyeleriyle Yüz yüze iletişim

\begin{tabular}{llrrrr}
\hline & Frequency & Percent & Valid Percent & Cumulative Percent \\
\hline Valid & Hiç iletişime geçmedim & 132 & 36,8 & 36,8 & 36,8 \\
& Yılda birkaç kez & 141 & 39,3 & 39,3 & 76,0 \\
& Ayda birkaç kez & 50 & 13,9 & 13,9 & 90,0 \\
& Haftada birkaç kez & 17 & 4,7 & 4,7 & 94,7 \\
& Her gün & 19 & 5,3 & 5,3 & 100,0 \\
\hline
\end{tabular}




Total $359 \quad 100,0 \quad 100,0$

Araştırmaya katılanların STK faaliyetlerini en çok hangi iletişim yöntemi ile takip ettikleri sorulmuştur. Ankete cevap verenlerin yarıdan fazlası STK'nın faaliyetlerinden sırasıyla Facebook $(\% 32,9)$ ve SMS $(\% 24,2)$ ile haberdar olduğunu belirtmiştir. Bunun yanında yerel STK temsilcisi $(\% 19,2)$ ve arkadaşlarından $(13,9)$ kulaktan kulağa iletişim diğer önemli iletişim araçlarıdır (Tablo 11). Cevap veren STK üyelerinin en az tercih ettikleri iletişim tekniği internet sayfası ve diğer sosyal medya (instegram, twitter vb.) araçlarıdır.

Tablo 11: STK'nın yapmış olduğu faaliyetleri en çok hangi iletişim yöntemi ile takip ediyorsunuz?

\begin{tabular}{|c|c|c|c|c|c|}
\hline & & Frequency & Percent & Valid Percent & $\begin{array}{r}\text { Cumulative } \\
\text { Percent }\end{array}$ \\
\hline \multirow[t]{7}{*}{ Valid } & îl temsilcisi ile yapılan toplantı ve il temsilcisinin anlattıklarından & 69 & 19,2 & 19,2 & 19,2 \\
\hline & Arkadaşlarımın anlattıklarından & 50 & 13,9 & 13,9 & 33,1 \\
\hline & SMS & 87 & 24,2 & 24,2 & 57,4 \\
\hline & İnternet sayfası & 21 & 5,8 & 5,8 & 63,2 \\
\hline & Facebook & 118 & 32,9 & 32,9 & 96,1 \\
\hline & Diğer Sosyal Medya (Instegram, Twtitter, vb.) & 14 & 3,9 & 3,9 & 100,0 \\
\hline & Total & 359 & 100,0 & 100,0 & \\
\hline
\end{tabular}

\section{SONUÇ VE ÖNERILER}

İnsanların ortak amaçlarını gerçekleştirmek üzere kurulan sivil toplum kuruluşlarının güçlendirilmesi ve gelişmesi için demokratikleşmeye ihtiyaç vardır. Yönetişim sürecinin verimli olabilmesi amacıyla tüm iletişim kanallarının yönetim ve üyeler tarafından yeterli bir düzeyde kullanılması gerekmektedir.

Bulgular araştırmaya katılan STK üyelerinin iletişim aracı olarak cep telefonu ve whatsapp ile iletişimi tercih ettiklerini göstermektedir. Üyeler yerel STK temsilcileri ile STK'nın başkan ve yönetim kuruluna göre daha fazla iletişim kurmaktadırlar. STK'nın faaliyetlerine ilişkin bilgi alma tercihlerinde ise yerel STK temsilcileri ile toplantı ve kulaktan kulağa iletişim önemlidir. STK üyeleri SMS ile de faaliyetleri takip etmektedirler. STK'nın faaliyetlerini takipte sosyal medya araçlarından facebook, diğer araçlara (instegram, twitter, internet sayfası vb.) göre daha fazla tercih edilmektedir. Bunun nedeninin STK üye yaş kitlesinin 36-49 yaş aralığında yoğunlaşması görülmektedir.

Yönetişim anlayışının örgütün tümünde benimsenmesi üyeler ile yönetim arasındaki iletişim ve işbirliğine bağlıdır. Yönetişim sürecinde örgüt yönetimi ve yerel temsilciler, üyelerin geribildirimde bulunmalarını sağlayacak iletişim kanallarını kullanmaları gerekmektedir. Üyelerin yönetime katılımı, fikirlerinin alınması ve yönetimde söz sahibi olmaları için iletişim araçlarının kullanımı ve ulaşılabilirliğin yüksek düzeyde olmalıdır. STK'larda gönüllü faaliyetlerin devam etmesinin de önemine vurgu yapılmalıdır. STK'ların gelişmesi ve güçlenmesi ülkenin de ekonomik, sosyo kültürel gelişimine katkı yapacaktır.

\section{KAYNAKÇA}

ABBotT, J. (2013). SHARING THE CiTY. LONDON: ROUTLEDGE. DOi:HTTPS://DOi.ORG/10.4324/9781315070759

Ataay, F. (2006). Yönetişim ve Sivil Toplum. Memleket:Siyaset-Yönetim Dergisi(1), 121-141.

Atak, M. (2005). Örgütlerde Resmi Olmayan İletişimin Yeri ve Önemi. Havacılık ve Uzay Teknolojileri Dergisi, 2(2), $59-67$.

Aydın, K., \& Aliyeva, M. (2019). Sivil Toplum Kuruluşlarının Web Sitelerinin Diyolojik İletişim Kullanım Düzeylerinin Belirlemeye Yönelik Bir Analiz (Rusya-Türkiye Karşılaştırması). Inönü Üniversitesi Iletişim Fakültesi, 4(2), 168-195.

Bozkanat, E. (2020). Sivil Toplum Kuruluşlarının Sosyal Medyada İlişki Kurma ve İletişim Stratejileri: Yeşilay Türkiye Facebook Sayfası Örneği. Erciyes Illetişim Dergisi, 7(1), 149-168. doi:http://10.17680/erciyesiletisim.595111

Çelikdemir, D. Z., \& Paker, İ. T. (2019). Örgütsel Değişimin Gerçekleşmesinde Örgütsel Illetişimin Önemi. Izmir iktisat Dergisi, 34(3), $431-441$.

Doğan, K. C. (2016). Postmodern Kamu Yönetimi, Yerel Yönetimler ve Katılım: Yerel Yönetişim Odaklı Bir Yaklaşım. Istanbul Gelişsim Üniversitesi Sosyal Bilimler Dergisi, 3(2), 73-99. doi:10.17336/igusbd.14844

Durğun, S. (2006). Örgüt Kültürü ve İletişim. Yüzüncü Yıl Üniversitesi, Eğitim Fakültesi Dergisi, 3, 112-132.

Efeoğlu, i. E., \& Çetin, S. (2012). Örgütsel İletşimin Değerlendirilmesi: Belediyelere Dair Uygulamalı Bir Çalışma. Ç.Ü. Sosyal Bilimler Enstitüsü Dergisi, 21(3), 185-204.

Ergle, D. (2015). Fostering Employee Engagement Through Gamification: AirBaltic Forecaster Tool. Management, 10(3), $219-234$.

Esen, H. (2014). Sivil Toplum Kuruluşlarında Iletişim. İstanbul: İnsamer.

Fidan, Y. (2011). Yönetimden Yönetişime: Kavramsal Bir Bakış. Yalova Sosyal Bilimler Dergisi(1), 5-10.

Gümüş, A. T. (2014). Dekmokrasilerde Sivil Toplum ve Devlet- Sivil Toplum iliş̧kisinde Karşılaşılabilecek Sorunlar. Gazi Üniversitesi Hukuk Dergisi, 18, 529-572.

Gündüz, A. Y. (2014). Küresel Dünyada Sivil Toplum Kuruluşlarının Ekonomik Kalkınmadaki Rolleri Üzerine Bir Değerlendirme. Akademik Araştırmalar ve Çalışmalar Dergisi, 6(10), 130-169. 
Karaçor, S., \& Şahin, A. (2004). Örgütsel İletişim Kurma Yöntemleri ve Karşılaşılan İletişim Engellerine Yönelik Bir Araştırma. Sü iiBF Sosyal ve Ekonomik Araştırmalar Dergisi, 97-117.

Kılıç, T., \& Saygılı, İ. (2019). Örgütsel İletişimin Örgütsel Sessizliğe Etkisinde Örgütsel Bağlılığın Aracı Değişken Rolü: Görgül Bir Araştırma. Uluslararası Iktisadi ve Idari Bilimler Dergisi, 5(1), 05-22.

Marques, J. F. (2010). Enhancing the quality of organizational communication A presentation of reflection-based criteria. Journal of Communication Management, 14(1), 47-58.

Öksüz, B. (2014). Yönetişim Sürecinde Kurumsal İletişimin Rolü ve Önemi. Gümüşhane Üniversitesi Illetişim Fakültesi Elektronik Dergisi, 2(4), 181-210.

Özdemir, B. P. (2010). Türkiye'deki Sivil Toplum Kuruluşları Web Sitelerinin Diyalojik İletişim Kapasiteleri Üzerine Bir İnceleme. Ankara Üniversitesi Sosyal Bilimler Enstitüsü Dergisi, 1(2)

Özer, M. H. (2008). Günümüz İtibariyle Sivil Toplum Kuruluşlarının İktisadi ve Sosyal Fonksiyonları. Elektronik Sosyal Bilimler Dergisi, 7(26), 86-97.

Özmutaf, N. M., \& Çelikli, S. (2010). Sivil Toplum Kuruluşlarında İletişim Kalitesini Etkileyen Boyutlar:Ampirik Bir Yaklaşım. Journal of Yasar University, 17(5), 2842-2858.

Öztürk, A. (1999). İletişim Sistemleri ve İletişim Teorisi. Selçuk Üniversitesi Illetişim Dergisi, 1(1).

Robbins, S. P., \& Judge, T. A. (2012). Örgütsel Davranış Organizational Behavior. (i. Erdem, Çev.) Ankara: Nobel.

Seyitoglu, F., \& Yüzbaşıoğlu, N. (2015). Organizational Communication in Five Star Hotels and Experienced Problems. International Journal of Science Culture and Sport (IntJSCS), 3(4), 126-139.

Sobacı, M. Z. (2007). Yönetişim Kavramı ve Türkiye'de Uygulanabilirliği Üzerine Değerlendirmeler. Yönetim Bilimleri Dergisi, 5(1), $219-235$.

Tarihi Bilgi. (2020, Kasım 28). Temmuz 01, 2021 tarihinde Tarihi Bilgi Web Sitesi: https://tarihibilgi.org/yonetisim/ adresinden alındı

Tutar, H. (2013). İşletme \& Yönetim Terimleri Ansiklopedik Sözlük. Ankara: Detay.

Walden, J. (2019). Communicating role expectations in a coworking office. Journal of Communication Management, 23(4), 316-330.

Yavuzyılmaz, O., \& Akıncı, A. (2017). Sivil Toplum Kuruluşları ve STK'larda Bütünleşik Illeşitim Faaliyetleri. International Congress on Politic, Economic and Social Studies (s. 326-332). Sarajevo : ICPESS.

Yıldırım, S., Arıkan, S., \& Aşan, Ö. (1996). Örgütlerin Yönetiminde İletişimin Önemi. Hacettepe Üniversitesi Iktisadi ve Idari Bilimler Fakültesi Dergisi, 19(1), 177-187.

Bu araştırma Havalimanları Güvenliği Memurları Derneği (SiHAGÜVDER) tarafından desteklenmiştir. 